Check for updates

Cite this: RSC Adv., 2019, 9, 29949

\title{
New synthesis of tetraoxaspirododecane-diamines and tetraoxazaspirobicycloalkanes $\uparrow$
}

\author{
Nataliya N. Makhmudiyarova, (D) * Kamil R. Shangaraev, Lilya U. Dzhemileva, * \\ Tatyana V. Tyumkina, Ekaterina S. Mescheryakova, Vladimir A. D'yakonov, \\ Askhat G. Ibragimov and Usein M. Dzhemilev
}

An efficient method for the synthesis of new spiro-tetraoxadodecanediamines and tetraoxazaspirobicycloalkanes has been developed by reactions of primary arylamines with gemdihydroperoxides and $\alpha, \omega$-dialdehydes (glyoxal, pentanedial) catalyzed by lanthanide catalysts. A potential pathway for formation of tetraoxaspirododecane-diamines and tetraoxazospirobicycloalkanes has been proposed that involves generation of intermediate tetraoxaspiroalkanediols under the reaction conditions. The structures of the crystalline products have been confirmed by XRD. It was shown that the synthesized tetraoxazaspirobicycloalkanes exhibit high cytotoxic activity against Jurkat, K562, and U937 tumor cultures and Fibroblasts.

Received 15th August 2019

Accepted 16th September 2019

DOI: $10.1039 / c 9 r a 06372 b$

rsc.li/rsc-advances

Presence of a heteroatom at $\alpha$-position relative to the

\section{Introduction}

Discovery of the antimalarial activity of the natural peroxide compound artemisinin stimulated the development of synthetic routes leading to novel cyclic peroxides. ${ }^{1}$ According to the published data, ${ }^{2}$ tetraoxaspirocycloalkanes demonstrate, in vivo, high antimalarial activity comparable with that of artemisinin. ${ }^{3}$ Known methods to synthesize tetraoxaspirocycloalkanes include reactions of gem-dihydroperoxides with $\alpha, \omega$-dihaloalkanes in the presence of $\mathrm{CsOH}$ in $\mathrm{DMF}^{4}$ or the same in the presence of $\mathrm{Ag}_{2} \mathrm{O}$ in $\mathrm{CH}_{2} \mathrm{Cl}_{2} \cdot{ }^{2,5}$ Additionally, tetraoxaspirocycloalkanes can be synthesized from unsaturated hydroperoxides $^{6}$ or (alkenyldioxy)cyclododecyl hydroperoxides. ${ }^{7}$ However, known synthetic methods to obtain tetraoxaspirocycloalkanes are hindered by significant drawbacks, such as low yields of the target products ${ }^{2,4,5}$ and a multistage synthetic process. $^{2,6}$ One of the effective methods for the synthesis of heteroatomic compounds of various structures in one stage with a good yield are catalytic multicomponent reactions. ${ }^{7-12}$

Present communication concerns a new approach to the synthesis of tetraoxaspirocycloalkanes having amine substituents at $\alpha$-positions relative to peroxide groups and of tetraoxazabicycloalkanes, via reactions of primary arylamines with gem-dihydroperoxides and $\alpha, \omega$-dialdehydes catalyzed by lanthanide complexes.

Institute of Petrochemistry and Catalysis, Russian Academy of Sciences, 141 Prospekt Oktyabrya, 450075 Ufa, Russian Federation. E-mail: natali-mnn@mail.ru; dzhemilev@mail.ru

$\dagger$ Electronic supplementary information (ESI) available. CCDC 1905323, 1905327, 1905330, 1905341, 1905334, 1905337. For ESI and crystallographic data in CIF or other electronic format see DOI: 10.1039/c9ra06372b peroxide group in such compounds as artemisinin, artemether, DU-1301, OZ277, ${ }^{3}$ veruculogen ${ }^{\mathbf{1 3}}$ and fumitremorgin, ${ }^{\mathbf{1 4}}$ and in bicyclic $^{15}$ and acyclic ${ }^{6} \alpha$-amino endoperoxides ${ }^{16}$ accounts for antimalarial and antimicrobial activities of these compounds. The data available on heteroatom-containing peroxides with high antimalarial activity ${ }^{\mathbf{1 1 3}}$ suggest that tetraoxaspirocycloalkanediamines could be useful for the development of antimalarial agents.

\section{Result and discusion}

During preliminary experiments it has been shown that the reaction of 1,1-dihydroperoxycyclohexane 1 with an equimolar amount of glyoxal 2 and $p$-chloroaniline $\mathbf{3 a}$ in selected conditions $\left(\sim 20{ }^{\circ} \mathrm{C}, \mathrm{THF}, 6 \mathrm{~h}\right)$ catalyzed by $5 \mathrm{~mol} \%$ of $\mathrm{Sm}\left(\mathrm{NO}_{3}\right)_{3} \cdot 6 \mathrm{H}_{2} \mathrm{O}$ gives $N, N^{\prime}$-bis(4-chlorophenyl)-7,8,11,12tetraoxaspiro[5.6]dodecane-9,10-diamine $4 a$ in $87 \%$ yield (Scheme 1). The $\mathrm{Sm}\left(\mathrm{NO}_{3}\right)_{3} \cdot 6 \mathrm{H}_{2} \mathrm{O}$ catalyst has been selected due to its activity in the syntheses of pentaoxacanes, ${ }^{17}$ tetraoxazaspiroalkanes, ${ }^{18,19}$ and hexaoxazadispiroalkanes. ${ }^{20}$ In an absence of the catalyst, the aforesaid reaction proceeds with the formation, along with the target product $\mathbf{4 a}(10 \%)$, of $\mathrm{N}$-(4-chlorophenyl)formamide (70\%) and cyclohexanone $(10 \%)$. Whether the reaction is conducted in presence of other lanthanide catalysts, the yield of $N, N^{\prime}$-bis(4chlorophenyl)-7,8,11,12-tetraoxaspiro[5.6]dodecane-9,10-

diamine 4 a decreases in the following order: $\mathrm{La}\left(\mathrm{NO}_{3}\right)_{3} \cdot 6 \mathrm{H}_{2} \mathrm{O}$ $(80 \%)>\mathrm{TbCl}_{3} \cdot 6 \mathrm{H}_{2} \mathrm{O}(73 \%)>\mathrm{Ho}\left(\mathrm{NO}_{3}\right)_{3} \cdot 5 \mathrm{H}_{2} \mathrm{O}(60 \%)>$ $\mathrm{DyCl}_{3} \cdot 6 \mathrm{H}_{2} \mathrm{O}(51 \%)>\mathrm{NdCl}_{3} \cdot 6 \mathrm{H}_{2} \mathrm{O}(50 \%)$.

In selected conditions $\left[5 \mathrm{~mol} \% \mathrm{Sm}\left(\mathrm{NO}_{3}\right)_{3} \cdot 6 \mathrm{H}_{2} \mathrm{O}, 20{ }^{\circ} \mathrm{C}, 6 \mathrm{~h}\right]$, arylamines ( $m, p$-fluoroanilines, $p$-bromoaniline) $\mathbf{3 b}$-e enter the 

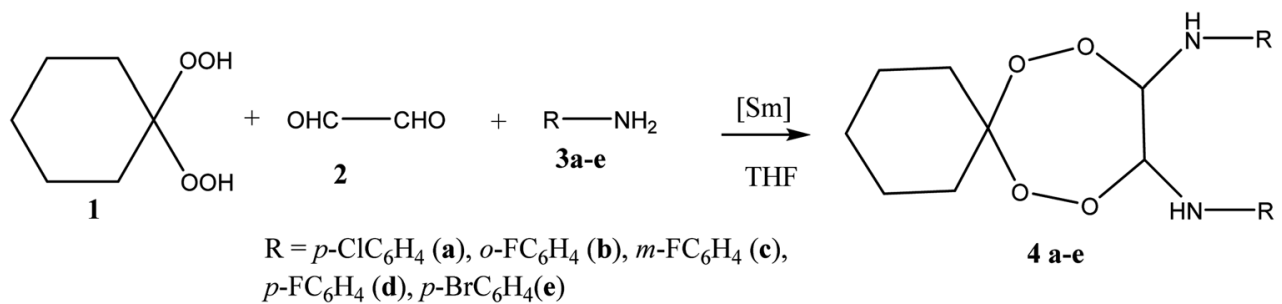

Scheme 1 Synthesis of tetraoxaspirododecane-diamines.
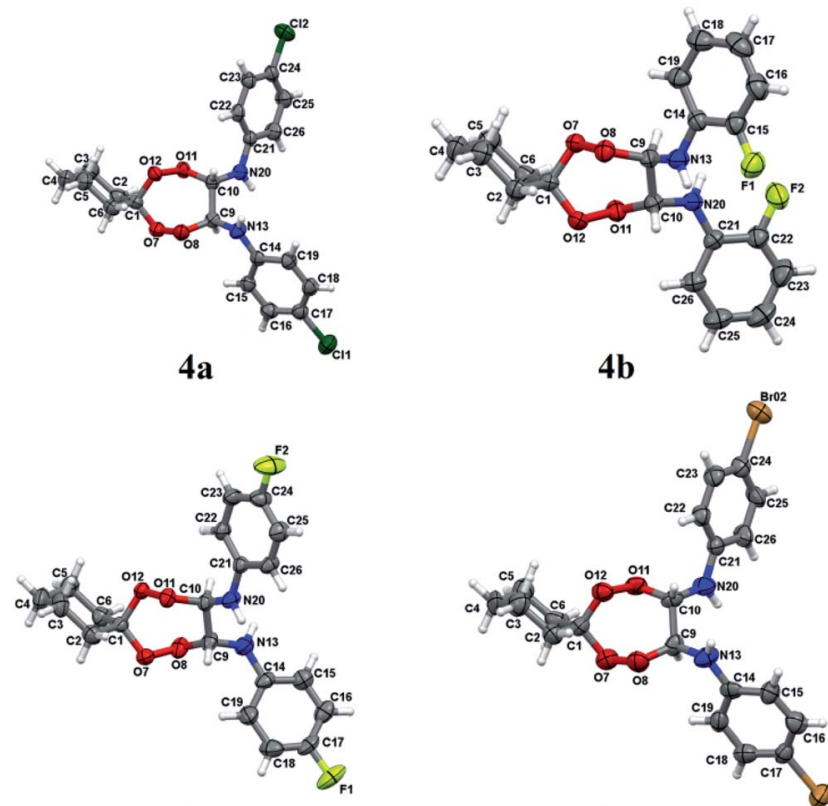

4d

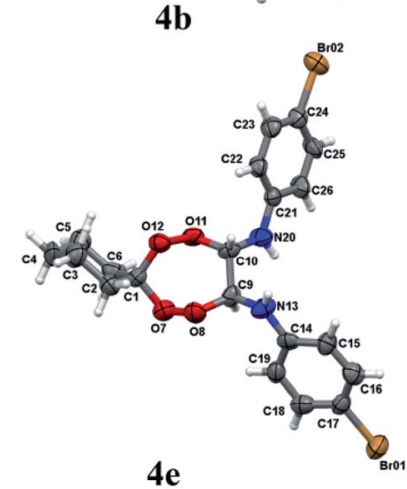

Fig. 1 Molecular structure of peroxides $4 a, b, d$, e. The atoms are depicted as thermal ellipsoids ( $p=50 \%$ ).

reaction with glyoxal 2 and 1,1-dihydroperoxycyclohexane 1 to result in formation of corresponding $N, N^{\prime}$-bis(aryl)-7,8,11,12tetraoxaspiro[5.6]dodecane-9,10-diamines $\mathbf{4 b - \mathbf { b }}$ in $84-90 \%$ yields (Scheme 1). In the experiments, choice of the solvent has been stipulated by the fact that both the reactants and the target products are highly soluble in THF.

Structures of $\quad N, N^{\prime}$-bis(aryl)-7,8,11,12-tetraoxaspiro[5.6] dodecane-9,10-diamines 4a-e have been established using ${ }^{1} \mathrm{H}$ and ${ }^{13} \mathrm{C}$ NMR spectrometry methods, MALDI TOF/TOF mass spectrometry and X-ray diffraction (Fig. 1). In ${ }^{1} \mathrm{H}$ NMR spectra, the signals for methine hydrogens atoms localized between the $\mathrm{N}$ and $\mathrm{O}$ atoms in the seven-membered rings resonate in a region between 4.60-4.75 ppm and emerge as a broadened singlet due to slow, in the NMR time scale, conformational flexibility of the ring, whereas methylene protons of the spiroalkane and alkane moieties occur as two multiplets in the regions between 1.40-1.70 ppm and 2.40-2.70 ppm. Aromatic protons resonate in a low-field region between $6.80-7.40 \mathrm{ppm}$. The mass spectrum of the heterocycles 4a-e displays the corresponding molecular ion peaks, accordingly.

Crystals for the compounds $\mathbf{4 a}, \mathbf{b}, \mathbf{d}, \mathbf{e}$ (Fig. 1) have been obtained from a solvent mixture of hexane and $\mathrm{Et}_{2} \mathrm{O}$ in $10: 1$ ratio, at room temperature. In the corresponding structures, a spiro-conjugated tetraoxepane ring adopts a twist boat conformation, similarly to the tetraoxepane derivative described in the literature. ${ }^{6}$ Chiral centers at atoms C9 and C10 adopt $S$ configuration in the compounds $\mathbf{4 a}, \mathbf{4 d}$, and $\mathbf{4 e}$ and $R$ configuration in the compound $\mathbf{4 b}$. $N$-aryl substituents are antioriented relative to each other, whereupon the torsion angle N20-C10-C9-N13 constitutes 73.1(3), -79.4(2), 68.7(4) and 74.3(8) for the compounds $\mathbf{4 a}, \mathbf{4 b}, \mathbf{4 d}$, and $\mathbf{4 e}$, respectively. The cyclohexane moiety in all compounds $\mathbf{4 a}, \mathbf{b}, \mathbf{d}, \mathbf{e}$ adopts a chair conformation. In all molecules, the nitrogen atoms adopt a planar configuration (wherein the sum of angles at the

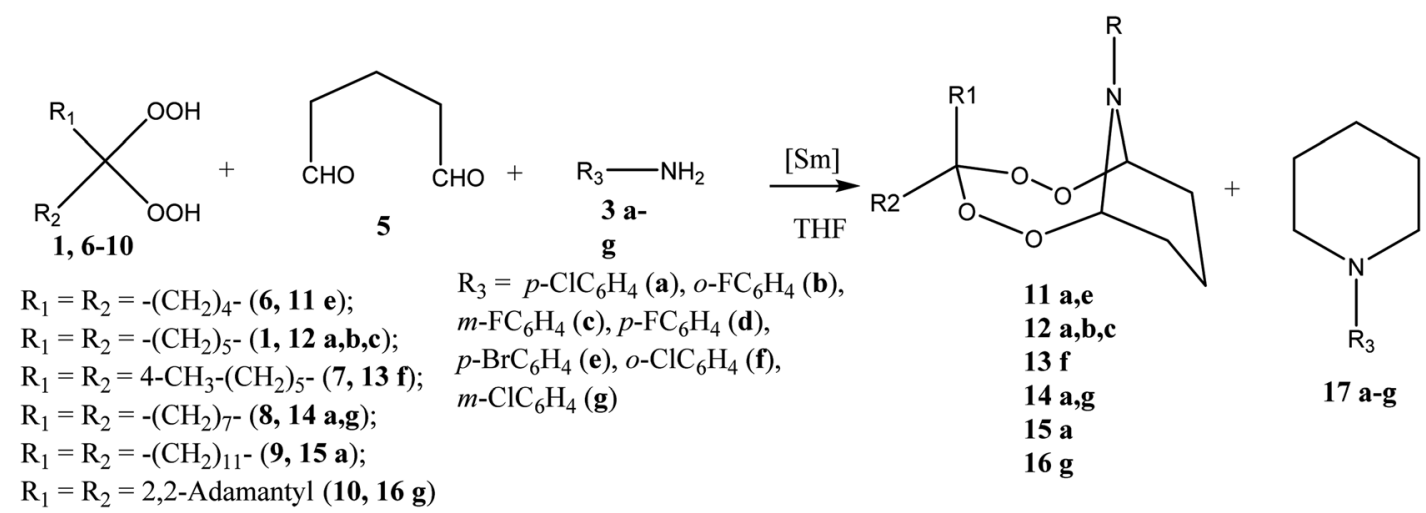

Scheme 2 Synthesis of tetraoxazaspirobicycloalkanes. 


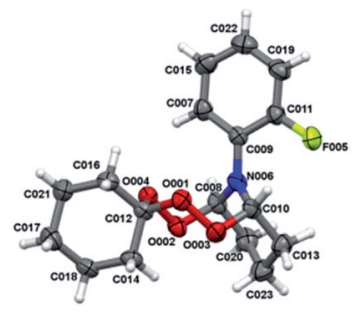

Fig. 2 Molecular structure of peroxide 12b. The atoms are depicted as thermal ellipsoids ( $p=50 \%$ ).

nitrogen atom is $\sim 360^{\circ}$ ), due to conjugation between the $\pi$ system of the aromatic substituent and an unshared pair of electrons at the nitrogen atom. The lengths of peroxide bonds are provided within a range of 1.458 to $1.468 \AA$.

In order to expand the scope of applicability of the method developed hereby, we have conducted a reaction of pentane-1,5dial 5 with gem-bis-hydroperoxides and primary amines. In conditions determined for the cyclocondensation of glyoxal 2 (5 mol\% $\mathrm{Sm}\left(\mathrm{NO}_{3}\right)_{3} \cdot 6 \mathrm{H}_{2} \mathrm{O}, 20{ }^{\circ} \mathrm{C}, 6 \mathrm{~h}$ ), the pentane-1,5-dial 5 enters the reaction with gem-bis-hydroperoxides and primary amines to give tetraoxazaspirobicycloalkanes (Scheme 3). In the reaction, the 1,1-dihydroperoxycycloalkane compounds based on cyclohexane 1, cyclopentane 6, 4-methylcyclohexane 7, cyclooctane 8, dodecane $\mathbf{9}$ and adamantane $\mathbf{1 0}$ have been utilized as gem-bis-hydroperoxides, whereas arylamines $\mathbf{3 a - g}$ have been utilized as the primary amines. The results obtainable in selected cyclocondensation conditions [pentane-1,5dial : gem-bis-hydroperoxide : arylamine : $\mathrm{Sm}\left(\mathrm{NO}_{3}\right)_{3} \cdot 6 \mathrm{H}_{2} \mathrm{O}=$ $1: 1: 1: 0.05(\mathrm{~mol} / \mathrm{mol})$; THF; $20^{\circ} \mathrm{C}$ ] indicate that the method thus developed is an efficient tool for the selective synthesis of bicyclic tetraoxazaspirobicycloalkanes 11-16 (71-83\%) (Scheme 2). $N$-arylpiperidines $\mathbf{1 7} \mathbf{a}-\mathbf{g}^{\mathbf{2 1}}$ were isolated as by-products of the reaction with a yield not exceeding $25 \%$.

Crystals for the compound 12b (Fig. 2) have been obtained from a solvent mixture of hexane and $\mathrm{Et}_{2} \mathrm{O}$ in $10: 1$ ratio, at room temperature.

According to the X-ray diffraction data, a tetraoxazocane ring adopts a boat chair conformation, whereas cyclohexane and pyran rings adopt the chair conformation. Bond lengths of the peroxide bonds O001-O003 and O002-O004 constitute 1.4692 (14) and 1.4612 (14) A, respectively. The nitrogen atom N006 in

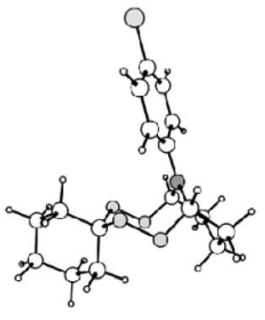

A $0.0 \mathrm{kcal} / \mathrm{mol}$

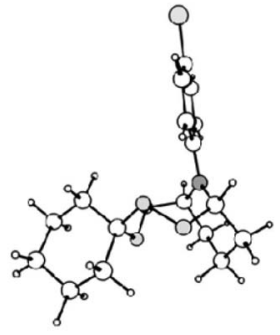

B $0.9 \mathrm{kcal} / \mathrm{mol}$

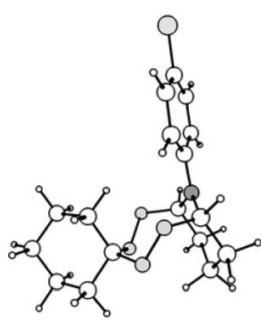

C $3.5 \mathrm{kcal} / \mathrm{mol}$
Fig. 3 Optimized structures of the lowest energy conformers of tetraoxazaspirobicycloalkanes.



Scheme 3 Synthesis of tetraoxaspirocycloalkanediols.

the compound 12b adopts a planar conformation similarly to that occurring in the compounds $\mathbf{4 a}, \mathbf{b}, \mathbf{d}$, e (with the sum of angles at the nitrogen, $\sum$ N006 $=359.7^{\circ}$ ).

As can be viewed from the figure, in a crystal phase the diperoxide moiety in the bicyclic structure adopts the chair conformation, while in solution a multicomponent conformational equilibrium exists, which is typical of both triperoxide ${ }^{20}$ and azadiperoxide ${ }^{18,19}$ compounds. Thus, in the ${ }^{13} \mathrm{C}$ NMR spectra of the synthesized compounds 11-16, three signals with similar chemical shifts can be observed in a region between 85.92-86.87 ppm for each said compound, instead of individual signals characteristic of the bridgehead tertiary carbon atoms. At the same time, the methine protons also exhibit signals split into components with different intensity in the matching region 5.36-5.83 ppm of the ${ }^{1} \mathrm{H}$ NMR spectra. By the way of an example, for the compound $\mathbf{1 2 a}$, the integrated intensity ratio for signals at $5.83 \mathrm{ppm}, 5.68 \mathrm{ppm}$, and $5.37 \mathrm{ppm}$ constitutes $1: 8: 1$, which correlates with the carbon signals at $85.92 \mathrm{ppm}, 86.87 \mathrm{ppm}$, and $86.75 \mathrm{ppm}$, respectively, according to the data obtained by heteronuclear 2D HSQC spectroscopy. In order to assign signals in the NMR spectra and by using quantum chemical method B3LYP/6-31G(d,p), six stable conformers have been identified on a potential energy surface of the bicyclic tetraoxazaspiroalkane molecule 12a having the spirohexane substituent in the chair conformation. ${ }^{22}$ Three the most energetically favorable conformers are shown in Fig. 3 as preferred candidates for the structures observed in the NMR spectra.

According to the calculated data, the global minimum corresponds to a conformer A that occurs in the crystal phase. Slightly higher in energy conformational states of the spiroaminodiperoxide moiety are the twist chair (B) and the chair (C). For the conformation $\mathbf{B}$, a conformation $\mathbf{B}^{\prime}$ of similar energy may exist, due to a lack of symmetry upon rigid fixation of rotational position of the $\mathrm{N}$-substituent and the spiro moiety. Symmetry violation is also possible in an event of ortho- or meta-

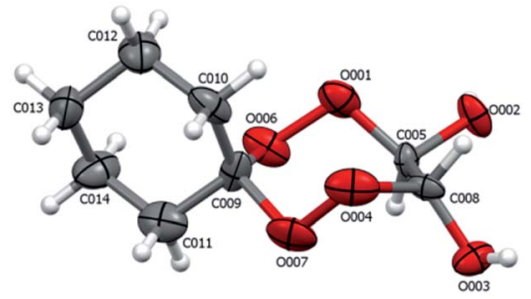

Fig. 4 Structure of compound 19 according to X-ray diffraction. The atoms are depicted as thermal ellipsoids $(p=50 \%)$. 
Table 1 Cytotoxic activities in vitro of compounds 4a, b, 11a, e, 12b, c, 15a measured on tumor cell cultures (Jurkat, K562, U937, Fibroblasts) ( $\mu$ M)

\begin{tabular}{llrrr}
\hline C-d & Jurkat $\left(\mathrm{IC}_{50}, \mu \mathrm{M}\right)$ & $\mathrm{K} 562\left(\mathrm{IC}_{50}, \mu \mathrm{M}\right)$ & U937 $\left(\mathrm{IC}_{50}, \mu \mathrm{M}\right)$ & Fibroblasts $\left(\mathrm{IC}_{50}, \mu \mathrm{M}\right)$ \\
\hline $\mathbf{1 1 e}$ & $13.51 \pm 0.72$ & $12.38 \pm 0.67$ & $16.44 \pm 1.43$ & $127.63 \pm 2.59$ \\
$\mathbf{1 1 a}$ & $63.29 \pm 2.25$ & $45.13 \pm 1.36$ & $42.19 \pm 1.24$ & $231.42 \pm 3.88$ \\
$\mathbf{1 2 c}$ & $17.39 \pm 1.87$ & $12.35 \pm 1.18$ & $11.49 \pm 0.84$ & $145.19 \pm 3.47$ \\
$\mathbf{1 4 g}$ & $272.57 \pm 5.68$ & $45.87 \pm 1.73$ & $40.87 \pm 1.58$ & $368.68 \pm 4.53$ \\
$\mathbf{1 2 b}$ & $15.48 \pm 0.31$ & $15.09 \pm 0.18$ & $14.83 \pm 0.24$ & $129.42 \pm 2.37$ \\
$\mathbf{1 5 a}$ & $118.23 \pm 2.74$ & $61.34 \pm 2.08$ & $59.17 \pm 1.79$ & $389.23 \pm 4.69$ \\
$\mathbf{4 b}$ & $52.91 \pm 1.41$ & $28.37 \pm 1.34$ & $26.45 \pm 1.17$ & $249.37 \pm 3.91$ \\
$\mathbf{4 a}$ & $>500$ & $106.24 \pm 3.95$ & $141.28 \pm 4.33$ &
\end{tabular}

substitutions in the aromatic ring, which can cause doubling of the observed set of signals. Additionally, any changes in the bicyclic cage lead to a sharp increase in energy up to $28 \mathrm{kcal} \mathrm{mol}^{-1}$ and higher (ESI, $\dagger$ conformers $\mathbf{D}$ and E); therefore, these changes are unlikely.

Presumably, the scheme of formation of spiro-tetraoxepanes includes the initial formation of tetraoxaspirocycloalkanediols, which then undergo condensation with primary amines to give the target products. This assumption was verified by conducting the synthesis of tetraoxaspirocycloalkanediols $\mathbf{1 8 - 2 0}$ by the reaction of 1,1-dihydroperoxycycloalkanes $\mathbf{1}, \mathbf{6}$, and 7 with glyoxal 2 in the presence of $5 \mathrm{~mol} \%$ of the $\mathrm{Sm}\left(\mathrm{NO}_{3}\right)_{3} \cdot 6 \mathrm{H}_{2} \mathrm{O}$ catalyst (Scheme 3). Without a catalyst, the yield of diols 17-19 did not exceed $10 \%$.

According to X-ray diffraction data for compounds 19 (Fig. 4), in the crystalline state, the tetraoxepane and cyclohexane moieties exist in the chair conformation. Like in structure $\mathbf{4 b}$, the chiral centers at the $\mathrm{C} 005$ and $\mathrm{C} 008$ carbon atoms have the $R$ configuration.

Cytotoxicity of azaperoxide based compounds is well known, ${ }^{3,13,14,19,20 b, 23}$ so screened the representative compounds for their cytotoxicity activity against Jurkat, K562, U937 Fibroblasts cell lines and results are summarized in Table 1.

It was found that the synthesized spirotetraoxadodecanediamines $\mathbf{4 a}, \mathbf{f}$ and tetraoxazaspirobicycloalkanes 11a, e, 12b, c, 14g, 15a exhibit a cytotoxic effect on all selected tumor cell lines in a wide range from 11.49 to $>500 \mu \mathrm{M}$. The most potent cytotoxic activity was shown by peroxides 11e, 12c and 12b synthesized by the reaction of 1,1dihydroperoxycyclopentane 6 or 1,1-dihydroperoxycyclohexane 1 and fluorine(bromine)arylamines. The replacement of bromine or fluorine atoms with chlorine atom in the phenyl substituent of the studied peroxides 11a, 14g and 15a leads to a significant decrease in their cytotoxicity, with a pronounced selective effect on myelocytic (K562) and monocytic (U937) cell cultures, in comparison with the cytotoxicity of the studied compounds to lymphocytes of the Jurkat line. At the same time, spiro-tetraoxadodecanediamines with two fluoroaromatic substituents $\mathbf{4 b}$ or chloroaromatic $\mathbf{4 a}$ fragments showed less cytotoxicity compared to tetraoxazaspirobicycloalkanes 11a, e, 12b, c, 14g, 15a.

The synthesized compounds have a selectivity index (SI) with respect to all tumor cells from 4 to $10\left(\mathrm{SI}=\mathrm{IC}_{50}\right.$ Fibroblasts $/ \mathrm{IC}_{50}$ cancer cells).

\section{Conclusions}

Hence, a versatile method has been developed for the synthesis of new spiro-tetraoxepanediamines and tetraoxazaspirobicycloalkanes by the reactions of primary arylamines with gem-dihydroperoxides and $\alpha, \omega$-dialdehydes in presence of lanthanide catalysts. The method thus developed markedly expands structural diversity of nitrogen-containing cyclic diperoxide derivatives and, in most cases, allows synthesizing these compounds with higher yields (up to 95\%) and selectivity. In addition, it was shown that the synthesized spirotetraoxepanediamines and tetraoxazaspirobicycloalkanes exhibit high cytotoxic activity against Jurkat, K562, U937 tumor cultures and Fibroblasts.

\section{Experimental section}

\section{General remarks}

All reactions were performed at room temperature in air in round-bottom flasks equipped with a magnetic stir bar. The NMR spectra were recorded on a Bruker Avance 500 spectrometer at $500.17 \mathrm{MHz}$ for ${ }^{1} \mathrm{H}$ and $125.78 \mathrm{MHz}$ for ${ }^{13} \mathrm{C}$ according to standard Bruker procedures. $\mathrm{CDCl} 3$ was used as the solvent, and tetramethylsilane, as the internal standard. The mixing time for the NOESY experiments was $0.3 \mathrm{~s}$. Mass spectra were recorded on a Bruker Autoflex III MALDI TOF/TOF instrument with $\alpha$-cyano-4-hydroxycinnamic acid as a matrix. Samples were prepared by the dried droplet method. The $\mathrm{C}, \mathrm{H}$, and $\mathrm{N}$ were quantified by a Carlo Erba 1108 analyzer. The oxygen content was determined on a Carlo Erba 1108 analyzer. The progress of reactions was monitored by TLC on Sorbfil (PTSKh-AF-A) plates, with a $5: 1$ hexane : EtOAc mixture as the eluent and visualization with $\mathrm{I}_{2}$ vapor. For column chromatography, silica gel MACHEREY-NAGEL $(0.063-0.2 \mathrm{~mm})$ was used.

All calculations were carried out using a program Gaussian 09. Geometric parameter optimization, vibrational frequency analysis, and calculation of entropy and thermodynamic corrections to the total energy of the compounds were carried out on the B3LYP functional ${ }^{18}$ using the $6-31 \mathrm{G}(\mathrm{d}, \mathrm{p})$ basis set. No limitation was imposed on the changes in the geometric parameters of the subsystems studied. Thermodynamic parameters were determined at $298 \mathrm{~K}$. The minima were confirmed through the calculation of the force constant (Hessian) matrix and the analysis of the resulting frequencies. 
All minima were verified to have no negative frequencies. Visualization of quantum chemical data was carried out with the programs ChemCraft. ${ }^{24}$

The X-ray diffraction measurements for compounds $\mathbf{4 a}, \mathbf{4 b}$, 4d, 4e, 12b, 19 were performed on an XCalibur Gemini Eos automated four-circle diffractometer (graphite monochromator, MoK $\alpha$ radiation, $\lambda=0.71073 \AA$, $\omega$-scan mode, $2 \theta_{\text {max }}$ $\left.=62^{\circ}\right)$ at ambient temperature (293-298 K). Collected data were processed using the program CrysAlisPro. ${ }^{25}$ Structures determinations were carried out with the OLEX2 program. ${ }^{26}$ The structures were solved by direct methods and refined by the fullmatrix least-squares method in the anisotropic approximation for non-hydrogen atoms. All hydrogen atoms are generated using the proper HFIX command and refined isotropically using the riding model. The calculations were performed using the SHELX program package. ${ }^{27}$ The molecular plots were drawn using mercury. ${ }^{28}$

The synthesis of the gem-dihydroperoxides $\mathbf{1 ,} \mathbf{6 - 1 0}$ was as reported in the literature. ${ }^{29}$ THF was freshly distilled over $\mathrm{LiAlH}_{4}$. Glyoxal was used as aqueous solution (40\%).

\section{Cell culturing}

Human cancer cell line HeLa was obtained from the HPA Culture Collections (UK). Cells (Jurkat, K562, U937, Fibroblasts) were purchased from Russian Cell Culture Collection (Institute of Cytology of the Russian Academy of Sciences) and cultured according to standard protocols and sterile technique. The cell lines were shown to be free of viral contamination and mycoplasma. Cells were maintained in RPMI 1640 (Jurkat, K562, U937, Fibroblast) (Gibco) supplemented with $4 \mu \mathrm{M}$ glutamine, 10\% FBS (Sigma) and 100 units per ml penicillin-streptomycin (Sigma). All types of cells were grown in an atmosphere of $5 \%$ $\mathrm{CO}_{2}$ at $37{ }^{\circ} \mathrm{C}$. The cells were subcultured at 2-3 days intervals. Cells were then seeded in 24 well plates at $5 \times 10^{4}$ cells per well and incubated overnight. Jurkat, K562, U937, Fibroblast cells were subcultured at 2 day intervals with a seeding density of $1 \times$ $10^{5}$ cells per 24 well plates in RPMI with $10 \%$ FBS.

\section{Cytotoxicity assay}

Viability (live/dead) assessment was performed by staining cells with 7-AAD (7-aminoactinomycin D) (Biolegend). After treatment cells were harvested, washed 1-2 times with phosphatebuffered saline (PBS) and centrifuged at $400 \mathrm{~g}$ for $5 \mathrm{~min}$. Cell pellets were resuspended in $200 \mu \mathrm{L}$ of flow cytometry staining buffer (PBS without $\mathrm{Ca}^{2+}$ and $\mathrm{Mg}^{2+}, 2.5 \% \mathrm{FBS}$ ) and stained with $5 \mu \mathrm{L}$ of 7 -AAD staining solution for $15 \mathrm{~min}$ at room temperature in the dark. Samples were acquired on NovoCyte TM 2000 Flow Cytometry System (ACEA) equipped with $488 \mathrm{~nm}$ argon laser. Detection of 7-AAD emission was collected through a $675 / 30 \mathrm{~nm}$ filter in the FL4 channel.

Cyclocondensation reactions of primary arylamines with gemdihydroperoxides and $\alpha, \omega$-dialdehydes (glyoxal, pentanedial) catalyzed by $\mathrm{Sm}\left(\mathrm{NO}_{3}\right)_{3} \cdot 6 \mathrm{H}_{2} \mathrm{O}$

General procedure: a Schlenk vessel mounted on a magnetic stirrer was charged at $\sim 20{ }^{\circ} \mathrm{C}$ with tetrahydrofuran $(5 \mathrm{ml}), \alpha, \omega$ - dialdehydes (glyoxal, pentanedial) $(10 \mathrm{mmol})$, and specified gem-dihydroperoxides $(10 \mathrm{mmol}) .{ }^{29}$ Then $\mathrm{Sm}\left(\mathrm{NO}_{3}\right)_{2} \cdot 6 \mathrm{H}_{2} \mathrm{O}$ (0.062 g, $5 \mathrm{~mol} \%$ relative to 1,1'-peroxybis(1hydroperoxycycloalkane)) was added. The reaction mixture was stirred at $\sim 20^{\circ} \mathrm{C}$ for $1 \mathrm{~h}$, after which primary arylamines (20 mmol) was added, and the reaction mixture was stirred at $\sim 20{ }^{\circ} \mathrm{C}$ for $6 \mathrm{~h}$ more. After completion of the reaction $\mathrm{H}_{2} \mathrm{O}(5 \mathrm{ml})$ and $\mathrm{CH}_{2} \mathrm{Cl}_{2}(5 \mathrm{ml})$ were added. The organic layer was separated, dried (anhydrous $\mathrm{MgSO}_{4}$ ) and concentrated to isolate products stable during storage at room temperature. Products of the reaction were purified by column chromatography on $\mathrm{SiO}_{2}$ using $10: 1 \mathrm{PE}: \mathrm{Et}_{2} \mathrm{O}$ as the eluent. The progress of reactions was monitored by TLC, with a $5: 1$ hexane : EtOAc mixture as the eluent, visualization was performed with $\mathrm{I}_{2}$ vapor.

\section{$N^{9}, N^{10}$-bis(4-Chlorophenyl)-7,8,11,12-tetraoxaspiro[5.6] dodecane-9,10-diamine $4 \mathrm{a}$}

White crystals; $0.37 \mathrm{~g}$ (87\% yield), $R_{\mathrm{f}} 0.77\left(\mathrm{PE} / \mathrm{Et}_{2} \mathrm{O}=10 / 1\right), \mathrm{mp}$ 120-122 ${ }^{\circ} \mathrm{C} .{ }^{1} \mathrm{H}$ NMR $\left(400 \mathrm{MHz}, \mathrm{CDCl}_{3}, 25^{\circ} \mathrm{C}\right): \delta=1.28-1.48(\mathrm{~m}$, $2 \mathrm{H}, \mathrm{CH}_{2}$ ), 1.69 (br.s, $4 \mathrm{H}, 2 \mathrm{CH}_{2}$ ), 1.77-1.89 (m, 4H, 2CH $\left.\mathrm{CH}_{2}\right), 5.57$ (br.s, 2H, 2CH), 7.13-7.15 (m, 4H, CH), 7.18-7.21 (m, 4H, CH). ${ }^{13} \mathrm{C} \mathrm{NMR}\left(100 \mathrm{MHz}, \mathrm{CDCl}_{3}, 25{ }^{\circ} \mathrm{C}\right.$ ): $\delta=22.6$ (conformer A), 22.8 (conformers B+C), 25.1, 31.2 (conformer A), 31.4 (conformers B+C), 85.1, 115.8, 116.3, 124.7, 128.6, 145.1. MALDI TOF/TOF, $m / z: 424[\mathrm{M}-\mathrm{H}]^{+}$. Anal. calcd for $\mathrm{C}_{20} \mathrm{H}_{22} \mathrm{Cl}_{2} \mathrm{~N}_{2} \mathrm{O}_{4}: \mathrm{C}, 56.48 ; \mathrm{H}$, 5.21 ; N, 6.59\%. Found: C, 56.46; H, 5.19; N, 6.57\%.

\section{$N^{9}, N^{10}$-bis(2-Fluorophenyl)-7,8,11,12-tetraoxaspiro[5.6] dodecane-9,10-diamine $4 \mathrm{~b}$}

White crystals; $0.33 \mathrm{~g}$ (85\% yield), $R_{\mathrm{f}} 0.75\left(\mathrm{PE} / \mathrm{Et}_{2} \mathrm{O}=10 / 1\right), \mathrm{mp}$ 134-136 ${ }^{\circ} \mathrm{C} .{ }^{1} \mathrm{H}$ NMR $\left(400 \mathrm{MHz}, \mathrm{CDCl}_{3}, 25^{\circ} \mathrm{C}\right): \delta=1.28-1.36(\mathrm{~m}$, $\left.2 \mathrm{H}, \mathrm{CH}_{2}\right), 1.43-1.45\left(\mathrm{~m}, 4 \mathrm{H}, 2 \mathrm{CH}_{2}\right), 1.60-1.61\left(\mathrm{~m}, 4 \mathrm{H}, 2 \mathrm{CH}_{2}\right)$, 5.70 (br.s, 2H, 2CH), 6.87-6.89 (m, 2H, CH), 7.02-7.10 (m, $4 \mathrm{H}$, $\mathrm{CH}), 7.18-7.24(\mathrm{~m}, 2 \mathrm{H}, \mathrm{CH}) .{ }^{13} \mathrm{C} \mathrm{NMR}\left(100 \mathrm{MHz}, \mathrm{CDCl}_{3}, 25{ }^{\circ} \mathrm{C}\right)$ : $\delta=22.6,25.1,29.7,89.7,111.5,114.5,115.2(J=19), 120.3(J=$ 17), 124.7, 142.5, $164.1(\mathrm{~J}=192)$. MALDI TOF/TOF, $m / z: 391[\mathrm{M}$ $-\mathrm{H}]^{+}$. Anal. calcd for $\mathrm{C}_{20} \mathrm{H}_{22} \mathrm{~F}_{2} \mathrm{~N}_{2} \mathrm{O}_{4}$ : C, 61.22; $\mathrm{H}, 5.65 ; \mathrm{N}, 7.14 \%$. Found: C, 61.20; H, 5.63; N, 7.11\%.

\section{$N^{9}, N^{10}$-bis(3-Fluorophenyl)-7,8,11,12-tetraoxaspiro[5.6] dodecane-9,10-diamine $4 \mathrm{c}$}

White crystals; $0.34 \mathrm{~g}$ (85\% yield), $R_{\mathrm{f}} 0.78\left(\mathrm{PE} / \mathrm{Et}_{2} \mathrm{O}=10 / 1\right), \mathrm{mp}$ 138-140 ${ }^{\circ} \mathrm{C} .{ }^{1} \mathrm{H}$ NMR $\left(400 \mathrm{MHz}, \mathrm{CDCl}_{3}, 25{ }^{\circ} \mathrm{C}\right): \delta=1.30-1.46(\mathrm{~m}$, $2 \mathrm{H}, \mathrm{CH}_{2}$ ), 1.61 (br.s, $4 \mathrm{H}, 2 \mathrm{CH}_{2}$ ), 1.77-1.84 (m, 4H, 2CH $\mathrm{CH}_{2}, 5.62$ (br.s, 2H, 2CH), 6.58-6.68 (m, 6H, CH), 7.18-7.25 (m, 2H, CH). ${ }^{13} \mathrm{C} \mathrm{NMR}\left(100 \mathrm{MHz}, \mathrm{CDCl}_{3}, 25{ }^{\circ} \mathrm{C}\right.$ ): $\delta=22.6$ (conformer A), 22.7 (conformers B+C), 25.0 (conformer A), 25.2 (conformers B+C), 31.2 (conformer A), 31.6 (conformers B+C), 88.2, $102.5(\mathrm{~J}=$ 7),111.1, 112.1, $107.2(J=17), 130.7(J=8), 145.6,163.8(J=$ 195). MALDI TOF/TOF, $m / z: 391[\mathrm{M}-\mathrm{H}]^{+}$. Anal. calcd for $\mathrm{C}_{20} \mathrm{H}_{22} \mathrm{~F}_{2} \mathrm{~N}_{2} \mathrm{O}_{4}$ : C, 61.22; H, 5.65; N, 7.14\%. Found: C, 61.19; H, $5.63 ; \mathrm{N}, 7.12 \%$. 
$N^{9}, N^{10}$-bis(4-Fluorophenyl)-7,8,11,12-tetraoxaspiro[5.6] dodecane-9,10-diamine 4d

White crystals; $0.35 \mathrm{~g}$ ( $88 \%$ yield), $R_{\mathrm{f}} 0.74\left(\mathrm{PE} / \mathrm{Et}_{2} \mathrm{O}=10 / 1\right), \mathrm{mp}$ 128-130 ${ }^{\circ} \mathrm{C} .{ }^{1} \mathrm{H}$ NMR $\left(400 \mathrm{MHz}, \mathrm{CDCl}_{3}, 25^{\circ} \mathrm{C}\right): \delta=1.28-1.45(\mathrm{~m}$, $2 \mathrm{H}, \mathrm{CH}_{2}$ ), 1.61 (br.s, $4 \mathrm{H}, 2 \mathrm{CH}_{2}$ ), 1.77-1.89 (m, $4 \mathrm{H}, 2 \mathrm{CH}_{2}$ ), 5.57 (br.s, 2H, 2CH), 6.80-6.88 (m, 4H, CH), 6.96-7.01 (m, 4H, CH). ${ }^{13} \mathrm{C}$ NMR $\left(100 \mathrm{MHz}, \mathrm{CDCl}_{3}, 25{ }^{\circ} \mathrm{C}\right): \delta=22.6,25.1,31.2$ (conformer A), 31.4 (conformers B+C), 89.4, 111.9, $116.0(J=18$ ), 121.6, 139.9, $157.7(J=190)$. MALDI TOF/TOF, $m / z: 391[\mathrm{M}-$ $\mathrm{H}]^{+}$. Anal. calcd for $\mathrm{C}_{20} \mathrm{H}_{22} \mathrm{~F}_{2} \mathrm{~N}_{2} \mathrm{O}_{4}$ : C, 61.22; H, 5.65; N, 7.14\%. Found: C, 61.20; H, 5.62; N, 7.12\%.

\section{$N^{9}, N^{10}$-bis(4-Bromophenyl)-7,8,11,12-tetraoxaspiro[5.6] dodecane-9,10-diamine $4 \mathrm{e}$}

White crystals; $0.43 \mathrm{~g}$ (90\% yield), $R_{\mathrm{f}} 0.72\left(\mathrm{PE} / \mathrm{Et}_{2} \mathrm{O}=10 / 1\right), \mathrm{mp}$ 122-124 ${ }^{\circ} \mathrm{C} .{ }^{1} \mathrm{H}$ NMR $\left(400 \mathrm{MHz}, \mathrm{CDCl}_{3}, 25^{\circ} \mathrm{C}\right): \delta=1.28-1.48(\mathrm{~m}$,

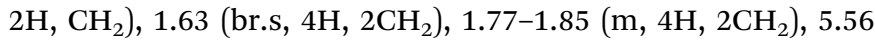
(br.s, 2H, 2CH), 6.73-6.75 (m, 4H, CH), 7.34-7.35 (m, 4H, CH). ${ }^{13} \mathrm{C}$ NMR (100 MHz, $\left.\mathrm{CDCl}_{3}, 25{ }^{\circ} \mathrm{C}\right): \delta=22.6, \quad 24.9,30.7$ (conformer A), 31.3 (conformers B+C), 89.3, 106.4, 112.2, 116.0, 121.5, 132.2. MALDI TOF/TOF, $m / z: 513[\mathrm{M}-\mathrm{H}]^{+}$. Anal. calcd for $\mathrm{C}_{20} \mathrm{H}_{22} \mathrm{Br}_{2} \mathrm{~N}_{2} \mathrm{O}_{4}$ : C, 46.72; H, 4.31; N, 5.45\%. Found: C, 46.70; H, 4.29; N, 5.43\%.

11-(4-Chlorophenyl)-2,3,5,6-tetraoxa-11-azaspiro[bicyclo[5.3.1] undecane-4,1'-cyclopentane] $11 \mathrm{a}$

Brown oil; $0.24 \mathrm{~g}$ (75\% yield), $R_{\mathrm{f}} 0.79\left(\mathrm{PE} / \mathrm{Et}_{2} \mathrm{O}=10 / 1\right) .{ }^{1} \mathrm{H}$ NMR $\left(500.17 \mathrm{MHz}, \mathrm{CDCl}_{3}, 25{ }^{\circ} \mathrm{C}\right): \delta=1.54-1.59\left(\mathrm{~m}, 1 \mathrm{H}, \mathrm{CH}_{\mathrm{a}}\right.$, conformers B+C), 2.40-2.44 (m, $1 \mathrm{H}, \mathrm{CH}_{\mathrm{b}}$, conformers $\left.\mathbf{B}+\mathbf{C}\right)$, 2.13-2.19 (m, $2 \mathrm{H}, \mathrm{CH}_{2}$, conformer $\left.\mathbf{A}\right), 1.53-2.10\left(\mathrm{~m}, 4 \mathrm{H}, 2 \mathrm{CH}_{2}\right)$, 1.70-1.97 (m, $\left.4 \mathrm{H}, 2 \mathrm{CH}_{2}\right), 2.45-2.35$ and $2.13-2.20$ and $1.76-1.82$ and $1.50-1.60\left(\mathrm{~m}, 4 \mathrm{H}, 2 \mathrm{CH}_{2}\right), 5.35-5.36(\mathrm{~m}, 2 \mathrm{H}, 2 \mathrm{CH}$, conformer B), $5.65(\mathrm{~s}, 2 \mathrm{H}, 2 \mathrm{CH}$, conformer $\mathrm{A}), 5.77(\mathrm{~s}, 2 \mathrm{H}, 2 \mathrm{CH}$, conformer C), 6.77-6.87 (m, 2H, CH), 7.13-7.20 (m, 2H, CH). ${ }^{13} \mathrm{C}$ NMR $\left(125.78 \mathrm{MHz}, \mathrm{CDCl}_{3}, 25{ }^{\circ} \mathrm{C}\right.$ ): $\delta=14.2$ (conformer $\mathrm{A}$ ), 16.0 (conformers B+C), 23.2 (conformer A), 24.3 (conformers B+C), 24.6 (conformer A), 26.4 (conformer A), 27.1 (conformers B+C), 33.5 (conformers $\mathbf{B}+\mathbf{C}$ ), 33.7 (conformer A), 34.0 (conformers B+C), 34.2 (conformer A), 88.2 (conformer B), 88.9 (conformer A), 89.1 (conformer C), 113.4, 114.2 (conformers B+C), 120.7 (conformer A), 128.0, 129.2 (conformer A), 140.2 (conformer B+C), 159.7. MALDI TOF/TOF, $m / z: 324[\mathrm{M}-\mathrm{H}]^{+}$. Anal. calcd for $\mathrm{C}_{16} \mathrm{H}_{20} \mathrm{ClNO}_{4}$ : C, 58.99; H, 6.19; N, 4.30\%. Found: C, 58.97; H, $6.17 ; \mathrm{N}, 4.27 \%$.

11-(4-bromophenyl)-2,3,5,6-tetraoxa-11-azaspiro[bicyclo[5.3.1] undecane-4,1'-cyclopentane] $11 \mathrm{e}$

Brown solid; $0.26 \mathrm{~g}$ (71\% yield), $R_{\mathrm{f}} 0.77\left(\mathrm{PE} / \mathrm{Et}_{2} \mathrm{O}=10 / 1\right), \mathrm{mp}$ 110-112 ${ }^{\circ} \mathrm{C} .{ }^{1} \mathrm{H}$ NMR $\left(500.17 \mathrm{MHz}, \mathrm{CDCl}_{3}, 25{ }^{\circ} \mathrm{C}\right): \delta=1.57-1.60$ $\left(\mathrm{m}, 1 \mathrm{H}, \mathrm{CH}_{\mathrm{a}}\right.$, conformers $\left.\mathbf{B}+\mathbf{C}\right), 2.43-2.47\left(\mathrm{~m}, 1 \mathrm{H}, \mathrm{CH}_{\mathrm{b}}\right.$, conformers $\mathbf{B}+\mathbf{C}), 2.13-2.20\left(\mathrm{~m}, 2 \mathrm{H}, \mathrm{CH}_{2}\right.$, conformer $\left.\mathbf{A}\right)$, 1.57$2.11\left(\mathrm{~m}, 4 \mathrm{H}, 2 \mathrm{CH}_{2}\right), 1.70-1.97\left(\mathrm{~m}, 4 \mathrm{H}, 2 \mathrm{CH}_{2}\right), 2.47-2.39$ and 2.13-2.20 and 1.74-1.80 and 1.52-1.60 (m, $\left.4 \mathrm{H}, 2 \mathrm{CH}_{2}\right), 5.27-5.28$ $(\mathrm{m}, 2 \mathrm{H}, 2 \mathrm{CH}$, conformer $\mathbf{B}), 5.67(\mathrm{~s}, 2 \mathrm{H}, 2 \mathrm{CH}$, conformer $\mathrm{A}), 5.81$ (s, 2H, 2CH, conformer C), 7.06-7.10 (m, 2H, CH), 7.35-7.39 (m,
2H, CH). ${ }^{13} \mathrm{C}$ NMR (125.78 $\left.\mathrm{MHz}, \mathrm{CDCl}_{3}, 25{ }^{\circ} \mathrm{C}\right): \delta=14.3$ (conformer A), 16.0 (conformers B+C), 23.3 (conformer A), 24.6 (conformers B+C), 24.9 (conformer A), 26.4 (conformer A), 27.1 (conformers B+C), 32.4 (conformers B+C), 33.5 (conformer A), 33.7 (conformers B+C), 34.6 (conformer A), 86.5 (conformer B), 87.1 (conformer A), 87.4 (conformer $\mathbf{C}$ ), 113.1, 119.7 (conformers B+C), 120.50 (conformer A), 124.5, 131.6 (conformer A), 132.4 (conformer B+C), 149.2. MALDI TOF/TOF, $m / z: 369[\mathrm{M}-\mathrm{H}]^{+}$. Anal. calcd for $\mathrm{C}_{16} \mathrm{H}_{20} \mathrm{BrNO}_{4}$ : C, 51.91; $\mathrm{H}$, 5.45 ; N, 3.78\%. Found: C, 51.89; H, 5.43; N, 3.76\%.

\section{1-(4-Chlorophenyl)-2,3,5,6-tetraoxa-11-azaspiro[bicyclo[5.3.1]} undecane-4,1'-cyclohexane] 12 a

Orange oil; $0.27 \mathrm{~g}$ (80\% yield), $R_{\mathrm{f}} 0.75\left(\mathrm{PE} / \mathrm{Et}_{2} \mathrm{O}=10 / 1\right) .{ }^{1} \mathrm{H} \mathrm{NMR}$ $\left(500.17 \mathrm{MHz}, \mathrm{CDCl}_{3}, 25{ }^{\circ} \mathrm{C}\right): \delta=1.57-1.62\left(\mathrm{~m}, 1 \mathrm{H}, \mathrm{CH}_{\mathrm{a}}\right.$, conformers $\mathbf{B}+\mathbf{C}), 2.11-2.20\left(\mathrm{~m}, 1 \mathrm{H}, \mathrm{CH}_{\mathrm{b}}\right.$, conformers $\left.\mathbf{B}+\mathbf{C}\right)$, 2.39-2.46 (m, $2 \mathrm{H}, \mathrm{CH}_{2}$, conformer A), 1.44-1.62 (m, $\left.4 \mathrm{H}, 2 \mathrm{CH}_{2}\right)$, 1.44-1.50 (m, 4H, 2 $\left.\mathrm{CH}_{2}\right), 1.78-1.87$ and 1.97-2.00 $(\mathrm{m}, 4 \mathrm{H}$, $\left.2 \mathrm{CH}_{2}\right), 1.31-1.34$ and $2.20-2.24\left(\mathrm{~m}, 4 \mathrm{H}, 2 \mathrm{CH}_{2}\right), 5.37-5.38(\mathrm{~m}$, $2 \mathrm{H}, 2 \mathrm{CH}$, conformer B), $5.68(\mathrm{~s}, 2 \mathrm{H}, 2 \mathrm{CH}$, conformer $\mathbf{A}), 5.84(\mathrm{~s}$, $2 \mathrm{H}, 2 \mathrm{CH}$, conformer $\mathrm{C}), 7.05-7.19(\mathrm{~m}, 1 \mathrm{H}, \mathrm{CH}), 7.21-7.22(\mathrm{~m}$, 1H, CH), 6.89-6.95 (m, 1H, CH), 7.17-7.19 (m, 1H, CH). ${ }^{13} \mathrm{C}$ NMR (125.78 MHz, $\mathrm{CDCl}_{3}, 25{ }^{\circ} \mathrm{C}$ ): $\delta=14.6$ (conformer A), 16.2 (conformers B+C), 22.0 (conformer A), 22.5 (conformers B+C), 22.7 (conformer A), 22.9 (conformer A), 25.3 (conformers B+C), 25.4 (conformers B+C), 26.4 (conformer A), 26.9 (conformers B+C), 28.7 (conformer A), 29.7 (conformers $\mathbf{B}+\mathbf{C}$ ), 30.7 (conformer B+C), 31.2 (conformer A), 85.9 (conformer B), 86.8 (conformer C), 86.9 (conformer A), 108.8 (conformers B+C), 109.5 (conformers A), 116.2 (conformers B+C), 116.8 (conformer A), 118.4 (conformers B+C), 119.0 (conformers A), 120.6 (conformers A), 121.3 (conformers B+C), 129.7 (conformers A), 129.9 (conformers B+C), 134.4, 151.2. MALDI TOF/TOF, $m / z: 338$ $[\mathrm{M}-\mathrm{H}]^{+}$. Anal. calcd for $\mathrm{C}_{17} \mathrm{H}_{22} \mathrm{ClNO}_{4}$ : C, 60.09; $\mathrm{H}, 6.53 \mathrm{~N}$, $4.12 \%$. Found: C, 60.07; H, $6.51 \mathrm{~N}, 4.10 \%$.

11-(2-Fluorophenyl)-2,3,5,6-tetraoxa-11-azaspiro[bicyclo[5.3.1] undecane-4,1'-cyclohexane] $12 \mathrm{~b}$

Brown crystals; $0.26 \mathrm{~g}$ (83\% yield), $R_{\mathrm{f}} 0.77\left(\mathrm{PE} / \mathrm{Et}_{2} \mathrm{O}=10 / 1\right), \mathrm{mp}$ 80-82 ${ }^{\circ} \mathrm{C}$. ${ }^{1} \mathrm{H}$ NMR $\left(500.17 \mathrm{MHz} \mathrm{CDCl}_{3}, 25{ }^{\circ} \mathrm{C}\right): \delta=1.56-1.60$ $\left(\mathrm{m}, 1 \mathrm{H}, \mathrm{CH}_{\mathrm{a}}\right), 2.14-2.24\left(\mathrm{~m}, 1 \mathrm{H}, \mathrm{CH}_{\mathrm{b}}\right), 1.60-1.66\left(\mathrm{~m}, 2 \mathrm{H}, \mathrm{CH}_{2}\right)$, 1.54-1.59 (m, 2H, $\mathrm{CH}_{2}$ ), 1.46-1.50 (m, 4H, 2CH $)$, 1.87-2.02 (m, $\left.4 \mathrm{H}, 2 \mathrm{CH}_{2}\right), 2.28-2.30\left(\mathrm{~m}, 2 \mathrm{H}, \mathrm{CH}_{2}\right), 5.15(\mathrm{~d}, 2 \mathrm{H}, J=10 \mathrm{~Hz}, 2 \mathrm{CH}$, conformer B), 5.34 (br.s, $2 \mathrm{H}, 2 \mathrm{CH}$, conformer A), 5.44-5.45 (m, $2 \mathrm{H}, 2 \mathrm{CH}$, conformer $\mathrm{C}), 6.93-7.12(\mathrm{~m}, 3 \mathrm{H}, \mathrm{CH}), 7.84-7.87(\mathrm{~m}$, $1 \mathrm{H}, \mathrm{CH}) .{ }^{13} \mathrm{C}$ NMR (125.78 $\left.\mathrm{MHz}, \mathrm{CDCl}_{3}, 25{ }^{\circ} \mathrm{C}\right): \delta=14.9$ (conformer A), 16.4 (conformers B+C), 22.0 (conformer A), 22.6 (conformers B+C), 22.9 (conformer B+C), 22.9 (conformer A), 25.4 (conformers B+C), 25.5 (conformers $\mathbf{B}+\mathbf{C}$ ), 26.1 (conformer A), 30.8 (conformers B+C), 31.6 (conformer A), 88.9 (conformer B), 89.3 (conformer A), 89.5 (conformer C), 108.7 (conformers B+C), $115.9(J=17$, conformers B+C), $116.1(J=17 \mathrm{~Hz}$, conformers A), $123.6(J=6), 124.4,124.8,137.9(J=6), 156.3(J=$ 193). MALDI TOF/TOF, $m / z: 322[\mathrm{M}-\mathrm{H}]^{+}$. Anal. calcd for $\mathrm{C}_{17} \mathrm{H}_{22} \mathrm{FNO}_{4}$ : C, 63.14; H, 6.86; N, 4.33\%. Found: C, 63.12; H, 6.84; N, $4.30 \%$. 
11-(3-Fluorophenyl)-2,3,5,6-tetraoxa-11-azaspiro[bicyclo[5.3.1] undecane-4,1'-cyclohexane] $12 \mathrm{c}$

Brown oil; $0.24 \mathrm{~g}$ (75\% yield), $R_{\mathrm{f}} 0.81\left(\mathrm{PE} / \mathrm{Et}_{2} \mathrm{O}=10 / 1\right) .{ }^{1} \mathrm{H}$ NMR (500.17 MHz, $\left.\mathrm{CDCl}_{3}, 25{ }^{\circ} \mathrm{C}\right): \delta=1.31-1.46\left(\mathrm{~m}, 4 \mathrm{H}, \mathrm{CH}_{2}, 2 \mathrm{CH}_{\mathrm{a}}\right)$, 1.48-1.62 (m, 5H, 2CH $\left.2, \mathrm{CH}_{\mathrm{a}}\right), 1.72-1.99\left(\mathrm{~m}, 4 \mathrm{H}, 2 \mathrm{CH}_{2}\right), 2.14-$ $2.19\left(\mathrm{~m}, 1 \mathrm{H}, \mathrm{CH}_{\mathrm{b}}\right), 2.22-2.25\left(\mathrm{~m}, 2 \mathrm{H}, \mathrm{CH}_{\mathrm{b}}\right), 5.37-5.39(\mathrm{~m}, 2 \mathrm{H}$, $2 \mathrm{CH}$, conformer C), 5.69 (br.s, $2 \mathrm{H}, 2 \mathrm{CH}$, conformer A), 5.85-5.86 (m, 2H, 2CH, conformer B), 6.59-6.68 (m, 1H, CH), 6.89-6.98 $(\mathrm{m}, 2 \mathrm{H}, \mathrm{CH}), 7.15-7.25(\mathrm{~m}, 1 \mathrm{H}, \mathrm{CH}) .{ }^{13} \mathrm{C}$ NMR $(125.78 \mathrm{MHz}$, $\mathrm{CDCl}_{3}, 25{ }^{\circ} \mathrm{C}$ ): $\delta=14.2$ (conformer $\mathbf{B}+\mathrm{C}$ ), 14.6 (conformer A), 21.0 (conformers B+C), 22.0 (conformer A), 22.5 (conformer B), 22.7 (conformer A), 22.8 (conformer C), 25.0 (conformer C), 25.3 (conformer B), 25.4 (conformer A), 26.4 (conformer A), 26.9 (conformer C), 27.0 (conformer B), 85.6 (conformer B), 86.7 (conformer C), 86.9 (conformer A), $104.8(J=17$, conformer C), $105.3(J=20$, conformer $\mathbf{B}), 105.9(J=20$, conformer $\mathbf{A}), 107.2(J$ $=17$ conformer $\mathbf{A}), 107.8(J=17$, conformers $\mathbf{B}+\mathbf{C}), 108.8$ (conformers B+C), 109.5 (conformer A), 113.3 (conformers B+C), 114.0 (conformer A), $129.7(J=8$, conformers A), $129.9(J=7$, conformer B), $130.4(J=8$, conformer C), $151.3(J=8$, conformers B+C), $151.8(J=8$, conformer A), $163.3(J=194)$. MALDI TOF/TOF, $m / z: 322[\mathrm{M}-\mathrm{H}]^{+}$. Anal. calcd for $\mathrm{C}_{17} \mathrm{H}_{22} \mathrm{FNO}_{4}$ : C, 63.14; H, 6.86; N, 4.33\%. Found: C, 63.11; H, $6.85 ; \mathrm{N}, 4.32 \%$.

\section{1-(2-Chlorophenyl)-4'-methyl-2,3,5,6-tetraoxa-11-azaspiro} [bicyclo[5.3.1] undecane-4,1'-cyclohexane] $13 \mathrm{f}$

Orange oil; $0.27 \mathrm{~g}$ (78\% yield), $R_{\mathrm{f}} 0.76\left(\mathrm{PE} / \mathrm{Et}_{2} \mathrm{O}=10 / 1\right) .{ }^{1} \mathrm{H}$ NMR $\left(500.17 \mathrm{MHz}, \mathrm{CDCl}_{3}, 25{ }^{\circ} \mathrm{C}\right): \delta=0.97\left(\mathrm{~d}, 3 \mathrm{H}, J=10 \mathrm{~Hz}, \mathrm{CH}_{3}\right.$, conformer A), 1.04 (d, 3H, J =10 Hz, $\mathrm{CH}_{3}$, conformer $\left.\mathbf{B}+\mathbf{C}\right), 1.58-$ 1.59 and 2.21-2.28 (m, 2H, $\left.\mathrm{CH}_{2}\right), 1.89-1.92$ and 2.14-2.19 (m, $\left.4 \mathrm{H}, 2 \mathrm{CH}_{2}\right), 1.59-1.61$ and $3.09-3.11\left(\mathrm{~m}, 4 \mathrm{H}, \mathrm{CH}_{2}\right), 1.23-1.73(\mathrm{~m}$, $\left.4 \mathrm{H}, 2 \mathrm{CH}_{2}\right), 1.98-2.03(\mathrm{~m}, 1 \mathrm{H}, \mathrm{CH}), 5.03-5.52(\mathrm{~m}, 2 \mathrm{H}, 2 \mathrm{CH}), 6.69-$ $6.78(\mathrm{~m}, 2 \mathrm{H}, 2 \mathrm{CH}), 6.97-7.40(\mathrm{~m}, 2 \mathrm{H}, 2 \mathrm{CH}) .{ }^{13} \mathrm{C}$ NMR $(125.78$ $\mathrm{MHz}, \mathrm{CDCl}_{3}, 25{ }^{\circ} \mathrm{C}$ ): $\delta=14.2$ (conformer $\mathrm{C}$ ), 15.0 (conformers A), 16.6 (conformer B), 21.6 (conformer A), 21.0 (conformers $\mathbf{B}+\mathbf{C}$ ), 25.9 and 26.0 and 26.7 (conformers $\mathbf{A}+\mathbf{B}+\mathbf{C}$ ), 30.9 and 31.2 (conformer B+C), 31.0 (conformers A), 31.4 (conformers B+C), 31.5 (conformer A), 31.7 and 31.9 (conformers B+C), 31.7 (conformer A), 34.8, 89.7 (conformer A), 89.6 and 89.8 and 89.9 (conformer $\mathbf{A}+\mathbf{B}+\mathbf{C}$ ), 109.6, 113.7 (conformers $\mathbf{B}+\mathbf{C}$ ), 115.9 (conformers A), 119.0 (conformer A), 119.3 and 119.4 (conformers B+C), 127.4 and 127.6 and 127.8 (conformers $\mathbf{B}+\mathbf{C}$ ), 127.6 (conformers A), 129.2 (conformers $\mathbf{B}+\mathbf{C}$ ), 129.4 (conformers A), 130.2 (conformers B+C), 130.5 (conformer A), 143.0 (conformer B+C), 147.1 (conformer A), MALDI TOF/TOF, $m / z: 322[\mathrm{M}-\mathrm{H}]^{+}$. Anal. calcd for $\mathrm{C}_{18} \mathrm{H}_{24} \mathrm{ClNO}_{4}: \mathrm{C}, 61.10 ; \mathrm{H}$, 6.84 ; N, 3.96\%. Found: C, 61.08; H, 6.82; N, 3.94\%.

11-(2-Chlorophenyl)-2,3,5,6-tetraoxa-11-azaspiro[bicyclo[5.3.1] undecane-4, $1^{\prime}$-cyclooctane] $14 a$

Orange oil; $0.26 \mathrm{~g}$ (70\% yield), $R_{\mathrm{f}} 0.77\left(\mathrm{PE} / \mathrm{Et}_{2} \mathrm{O}=10 / 1\right) .{ }^{1} \mathrm{H}$ NMR (500.17 MHz, $\left.\mathrm{CDCl}_{3}, 25{ }^{\circ} \mathrm{C}\right): \delta=1.56-1.59\left(\mathrm{~m}, 1 \mathrm{H}, \mathrm{CH}_{\mathrm{a}}\right), 2.14-$ $2.15\left(\mathrm{~m}, 1 \mathrm{H}, \mathrm{CH}_{\mathrm{b}}\right), 1.63-1.67$ and $1.51-1.53\left(\mathrm{~m}, 4 \mathrm{H}, 2 \mathrm{CH}_{2}\right), 2.38-$ $2.40\left(\mathrm{~m}, 2 \mathrm{H}, 2 \mathrm{CH}_{2}\right), 2.17-2.24$ and $1.95-2.00$ and $1.77-1.87(\mathrm{~m}$, $\left.6 \mathrm{H}, 3 \mathrm{CH}_{2}\right), 1.42-1.44$ and $1.63-1.67$ and $1.80-1.85(\mathrm{~m}, 4 \mathrm{H}$, $\left.2 \mathrm{CH}_{2}\right), 5.67(\mathrm{~s}, 2 \mathrm{H}, 2 \mathrm{CH}$, conformer $\mathrm{A}), 5.80(\mathrm{~s}, 2 \mathrm{H}, 2 \mathrm{CH}$, conformer $\mathbf{B}+\mathbf{C})$, 7.01-7.03 (m, 2H, 2CH, conformer A), 7.10$7.15(\mathrm{~m}, 2 \mathrm{H}, 2 \mathrm{CH}$, conformer $\mathbf{B}+\mathbf{C}), 6.96-6.97(\mathrm{~m}, 2 \mathrm{H}, 2 \mathrm{CH}$, conformer B+C), 7.19-7.27 (m, 2H, 2CH, conformer A). ${ }^{13} \mathrm{C} \mathrm{NMR}$ $\left(125.78 \mathrm{MHz}, \mathrm{CDCl}_{3}, 25{ }^{\circ} \mathrm{C}\right.$ ): $\delta=14.6$ (conformer $\mathbf{A}$ ), 16.3 (conformer B+C), 22.0 (conformers B+C), 22.3 (conformer A), 22.1, 26.4 (conformer A), 26.6 (conformer B+C), 31.2 (conformer A), 31.4 (conformer $\mathbf{B}+\mathbf{C}), \quad 86.0$ (conformer $\quad \mathbf{B}+\mathbf{C}), \quad 86.9$ (conformer A), 111.1, 119.0 (conformer A), 119.8 (conformer B+C), 124.5, 128.7 (conformers A), 129.0 (conformers B+C), 144.8. MALDI TOF/TOF, $m / z: 366[\mathrm{M}-\mathrm{H}]^{+}$. Anal. calcd for $\mathrm{C}_{19} \mathrm{H}_{26} \mathrm{ClNO}_{4}$ : C, 62.04; H, 7.12; N, 3.81\%. Found: C, 62.02; H, $7.10 ; \mathrm{N}, 3.79 \%$.

\section{1-(2-Chlorophenyl)-2,3,5,6-tetraoxa-11-azaspiro[bicyclo[5.3.1]} undecane-4, $1^{\prime}$-cyclooctane] $14 \mathrm{~g}$

Orange solid; $0.27 \mathrm{~g}$ (74\% yield), $R_{\mathrm{f}} 0.74\left(\mathrm{PE} / \mathrm{Et}_{2} \mathrm{O}=10 / 1\right), \mathrm{mp}$ 98-100 ${ }^{\circ} \mathrm{C} .{ }^{1} \mathrm{H}$ NMR (500.17 $\left.\mathrm{MHz}, \mathrm{CDCl}_{3}, 25{ }^{\circ} \mathrm{C}\right): \delta=1.46-1.51$ $\left(\mathrm{m}, 1 \mathrm{H}, \mathrm{CH}_{\mathrm{a}}\right), 2.09-2.19\left(\mathrm{~m}, 1 \mathrm{H}, \mathrm{CH}_{\mathrm{b}}\right), 1.38-1.69\left(\mathrm{~m}, 4 \mathrm{H}, 2 \mathrm{CH}_{2}\right)$, 2.34-2.36 and 1.38-1.50 (m, 2H, 2CH $), 1.29-1.84(\mathrm{~m}, 6 \mathrm{H}$, $\left.3 \mathrm{CH}_{2}\right), 1.34-1.40\left(\mathrm{~m}, 4 \mathrm{H}, 2 \mathrm{CH}_{2}\right), 5.61(\mathrm{~s}, 2 \mathrm{H}, 2 \mathrm{CH}$, conformer $\mathbf{A})$, $5.75(\mathrm{~s}, 2 \mathrm{H}, 2 \mathrm{CH}$, conformer $\mathrm{B}+\mathrm{C}), 6.45-6.47(\mathrm{~m}, 1 \mathrm{H}, \mathrm{CH}), 6.58-$ 6.59 (m, 1H, CH), 6.62-6.63 (m, 1H, CH), 6.95-7.19 (m, H, CH). ${ }^{13} \mathrm{C}$ NMR $\left(125.78 \mathrm{MHz}, \mathrm{CDCl}_{3}, 25{ }^{\circ} \mathrm{C}\right): \delta=14.2$ (conformer $\mathbf{A}$ ), 16.1 (conformer $\mathbf{B}+\mathbf{C}$ ), 22.0 (conformers A), 22.3 (conformer B+C), 24.7 (conformer A), 25.1 (conformer B+C), 25.7, 31.0 (conformer B+C), 31.4 (conformers A), 85.8 (conformer B), 86.7 (conformer C), 86.7 (conformer A), 113.3, 112.5 (conformer A), 113.2 (conformer B+C), 114.7, 117.9 (conformers A), 118.2 (conformers B+C), 129.7 (conformers B+C), 130.3 (conformers A), 134.3 (conformers B+C), 134.6 (conformers A), 147.4 (conformers B+C), 148.1 (conformers A). MALDI TOF/TOF, $m / z$ : $366[\mathrm{M}-\mathrm{H}]^{+}$. Anal. calcd for $\mathrm{C}_{19} \mathrm{H}_{26} \mathrm{ClNO}_{4}$ : C, 62.04; H, 7.12; N, $3.81 \%$. Found: C, 62.01; H, 7.09; N, 3.79\%.

11-(2-Chlorophenyl)-2,3,5,6-tetraoxa-11-azaspiro[bicyclo[5.3.1] undecane-4,1'-cyclododecane] $15 \mathrm{a}$

Orange crystal; $0.33 \mathrm{~g}$ (79\% yield), $R_{\mathrm{f}} 0.78\left(\mathrm{PE} / \mathrm{Et}_{2} \mathrm{O}=10 / 1\right), \mathrm{mp}$ 82-84 ${ }^{\circ} \mathrm{C}$. ${ }^{1} \mathrm{H}$ NMR $\left(500.17 \mathrm{MHz}, \mathrm{CDCl}_{3}, 25{ }^{\circ} \mathrm{C}\right): \delta=1.27-1.36$ $\left(\mathrm{m}, 12 \mathrm{H}, 6 \mathrm{CH}_{2}\right), 1.70-1.75\left(\mathrm{~m}, 2 \mathrm{H}, \mathrm{CH}_{2}\right), 1.27-1.98(\mathrm{~m}, 4 \mathrm{H}$, $\left.2 \mathrm{CH}_{2}\right), 2.15-2.20$ and $1.98-2.20\left(\mathrm{~m}, 4 \mathrm{H}, 2 \mathrm{CH}_{2}\right), 2.15-2.41(\mathrm{~m}$, $\left.2 \mathrm{H}, \mathrm{CH}_{2}\right), 5.35-5.36(\mathrm{~m}, 2 \mathrm{H}, 2 \mathrm{CH}$, conformer $\mathbf{B}), 5.66(\mathrm{~s}, 2 \mathrm{H}$, $2 \mathrm{CH}$, conformer $\mathbf{A}), 5.82$ (s, 2H, 2CH, conformer $\mathbf{C}), 7.03-7.08$ (m, 1H, CH), 7.15-7.21 (m, 2H, CH), 6.87-6.94 (m, 1H, CH). ${ }^{13} \mathrm{C}$ NMR (125.78 MHz, $\mathrm{CDCl}_{3}, 25{ }^{\circ} \mathrm{C}$ ): $\delta=14.2$ (conformer A), 16.1 (conformer B+C), 22.0 (conformers A), 22.3 (conformer $\mathbf{B}+\mathbf{C}$ ), 24.7 (conformer A), 25.1 (conformer $\mathbf{B}+\mathbf{C}$ ), 25.7, 31.0 (conformer B+C), 31.4 (conformers A), 85.8 (conformer B), 86.7 (conformer C), 86.7 (conformer A), 113.3, 112.5 (conformer A), 113.2 (conformer B+C), 114.7, 117.9 (conformers A), 118.2 (conformers B+C), 129.7 (conformers B+C), 130.3 (conformers A), 134.3 (conformers B+C), 134.6 (conformers A), 147.4 (conformers B+C), 148.1 (conformers A). MALDI TOF/TOF, $m / z$ : $366[\mathrm{M}-\mathrm{H}]^{+}$. Anal. calcd for $\mathrm{C}_{23} \mathrm{H}_{34} \mathrm{ClNO}_{4}$ : C, 65.16; H, 8.08; N, $3.30 \%$. Found: C, 65.12; H, 8.06; N, 3.28\%. 
11'-(3-Chlorophenyl)-2' ${ }^{\prime}, 3^{\prime}, 5^{\prime}, 6^{\prime}$-'tetraoxa-11' -azaspiro [adamantane-2,4'-bicyclo[5.3.1] undecane] 16g

Brown oil; $0.28 \mathrm{~g}$ (72\% yield), $R_{\mathrm{f}} 0.80\left(\mathrm{PE} / \mathrm{Et}_{2} \mathrm{O}=10 / 1\right) .{ }^{1} \mathrm{H}$ NMR (400 $\left.\mathrm{MHz}, \mathrm{CDCl}_{3}, 25{ }^{\circ} \mathrm{C}\right): \delta=1.66-1.74\left(\mathrm{~m}, 2 \mathrm{H}, \mathrm{CH}_{2}-\mathrm{Ad}\right), 1.77$ (m, 1H, CH-Ad, conformer A), 1.82-1.86 (m, 8H, $\left.\mathrm{CH}_{2}-\mathrm{Ad}\right)$, 1.952.01 (m, 4H, $\mathrm{CH}_{2}$-Ad, conformer A), 2.04-2.06 (m, 4H, $\mathrm{CH}_{2}-\mathrm{Ad}$ ), 2.10-2.17 (m, 4H, 2 $\mathrm{CH}_{2}$ ), 2.19-2.28 (m, 2H, $\mathrm{CH}_{2}$ ), 2.31 (br.s, $2 \mathrm{H}$, $\mathrm{CH}_{2}$-Ad), 2.39 (br.s, 1H, $\mathrm{CH}_{2}$-Ad, conformer A), 5.48-5.49 (m, $2 \mathrm{H}, 2 \mathrm{CH}$, conformer B), $5.68(\mathrm{~s}, 2 \mathrm{H}, 2 \mathrm{CH}$, conformer $\mathbf{A}), 5.81(\mathrm{~s}$, $2 \mathrm{H}, 2 \mathrm{CH}$, conformer $\mathrm{C}), 6.77-6.84(\mathrm{~m}, 1 \mathrm{H}, \mathrm{CH}), 6.89-6.95(\mathrm{~m}$, $1 \mathrm{H}, \mathrm{CH}), 7.02-7.13(\mathrm{~m}, 1 \mathrm{H}, \mathrm{CH}), 7.15-7.23(\mathrm{~m}, 1 \mathrm{H}, \mathrm{CH}) .{ }^{13} \mathrm{C}$ NMR (100 MHz, $\mathrm{CDCl}_{3}, 25{ }^{\circ} \mathrm{C}$ ): $\delta=14.6$ (conformer A), 16.3 (conformer B+C), 26.5, 27.1 (conformer B+C), 27.2 (conformer A), 30.3, 33.1 (conformer A), 33.6 (conformer $\mathbf{B}+\mathbf{C}$ ), 34.2 (conformers B+C), 34.4 (conformer A), 37.3 (conformer $\mathbf{B}+\mathbf{C}$ ), 37.4 (conformer A), 84.8 (conformer B), 86.1 (conformer C), 86.9 (conformer A), 110.9 (conformer B), 111.5 (conformer A), 112.6 (conformer C), 116.6 (conformers B+C), 116.9 (conformer A), 118.8 (conformers A), 119.1 (conformers B+C), 120.5 (conformer A), 121.4 (conformers B+C), 129.7, 151.3. MALDI TOF/TOF, $m / z$ : $390[\mathrm{M}-\mathrm{H}]^{+}$. Anal. calcd for $\mathrm{C}_{21} \mathrm{H}_{26} \mathrm{ClNO}_{4}$ : C, 64.36; H, 6.69; N, $3.57 \%$. Found: C, 64.33; H, 6.67; N, 3.55\%.

\section{Cyclocondensation reactions of gem-dihydroperoxides with glyoxal catalyzed by $\mathrm{Sm}\left(\mathrm{NO}_{3}\right)_{3} \cdot 6 \mathrm{H}_{2} \mathrm{O}$}

General procedure: a Schlenk vessel mounted on a magnetic stirrer was charged at $\sim 20{ }^{\circ} \mathrm{C}$ with tetrahydrofuran $(5 \mathrm{ml})$, glyoxal (10 $\mathrm{mmol})$, and specified gem-dihydroperoxides (10 mmol $){ }^{29}$ Then $\mathrm{Sm}\left(\mathrm{NO}_{3}\right)_{2} \cdot 6 \mathrm{H}_{2} \mathrm{O}\left(0.062 \mathrm{~g}, 5 \mathrm{~mol} \%\right.$ relative to $1,1^{\prime}-$ peroxybis(1-hydroperoxycycloalkane)) was added. The reaction mixture was stirred at $\sim 20{ }^{\circ} \mathrm{C}$ for $1 \mathrm{~h}$. After completion of the reaction $\mathrm{H}_{2} \mathrm{O}(5 \mathrm{ml})$ and $\mathrm{CH}_{2} \mathrm{Cl}_{2}(5 \mathrm{ml})$ were added. The organic layer was separated, dried (anhydrous $\mathrm{MgSO}_{4}$ ) and concentrated to isolate products stable during storage at room temperature. Products of the reaction were purified by column chromatography on $\mathrm{SiO}_{2}$ using $10: 1 \mathrm{PE}: \mathrm{Et}_{2} \mathrm{O}$ as the eluent. The progress of reactions was monitored by TLC, with a $5: 1$ hexane : EtOAc mixture as the eluent, visualization was performed with $I_{2}$ vapor.

\section{6,7,10,11-Tetraoxaspiro[4.6] undecane-8,9-diol 18}

White solid; $0.16 \mathrm{~g}$ ( $82 \%$ yield), $R_{\mathrm{f}} 0.79\left(\mathrm{PE} / \mathrm{Et}_{2} \mathrm{O}=10 / 1\right), \mathrm{mp}=$ 96-98 ${ }^{\circ} \mathrm{C} .{ }^{1} \mathrm{H}$ NMR (500.17 MHz, $\left.\mathrm{CDCl}_{3}, 25{ }^{\circ} \mathrm{C}\right): \delta=1.72-1.80$ (m, 4H, $\left.\mathrm{CH}_{2}\right)$ 1.90-2.04 (m, 4H, $\left.\mathrm{CH}_{2}\right), 5.15-5.22(\mathrm{~m}, 2 \mathrm{H}, 2 \mathrm{CH})$. ${ }^{13} \mathrm{C}$ NMR (125.78 $\left.\mathrm{MHz}, \mathrm{CDCl}_{3}, 25{ }^{\circ} \mathrm{C}\right): \delta=24.2,24.3,33.5,33.7$, 90.9, 91.1, 110.4. MALDI TOF/TOF, $m / z: 191[\mathrm{M}-\mathrm{H}]^{+}$. Anal. calcd for $\mathrm{C}_{7} \mathrm{H}_{12} \mathrm{O}_{6}: \mathrm{C}, 43.75 ; \mathrm{H}, 6.29 \%$. Found: $\mathrm{C}, 43.73 ; \mathrm{H}$, $6.27 \%$.

\section{7,8,11,12-Tetraoxaspiro[5.6]dodecane-9,10-diol 19}

White solid; $0.17 \mathrm{~g}$ ( $85 \%$ yield), $R_{\mathrm{f}} 0.76\left(\mathrm{PE} / \mathrm{Et}_{2} \mathrm{O}=10 / 1\right), \mathrm{mp}=$ 54-56 ${ }^{\circ} \mathrm{C} .{ }^{1} \mathrm{H}$ NMR $\left(500.17 \mathrm{MHz}, \mathrm{CDCl}_{3}, 25{ }^{\circ} \mathrm{C}\right): \delta=1.46-1.47$ (m, 4H, $\mathrm{CH}_{2}$ ), 1.59-1.64 (m, 2H, $\left.\mathrm{CH}_{2}\right), 1.88-1.90\left(\mathrm{~m}, 4 \mathrm{H}, \mathrm{CH}_{2}\right)$ 5.27-5.33 (m, 2H, 2CH). ${ }^{13} \mathrm{C}$ NMR (125.78 $\left.\mathrm{MHz} \mathrm{CDCl}_{3}, 25{ }^{\circ} \mathrm{C}\right)$ : $\delta=22.5,22.6,25.2,25.4,29.8,30.7,90.5$, 91.0, 113.5. MALDI
TOF/TOF, $m / z: 205[\mathrm{M}-\mathrm{H}]^{+}$. Anal. calcd for $\mathrm{C}_{8} \mathrm{H}_{14} \mathrm{O}_{6}: \mathrm{C}, 46.60$; H, 6.84\%. Found: C, 46.58; H, 6.81\%.

\section{3-Methyl-7,8,11,12-tetraoxaspiro[5.6]dodecane-9,10-diol 20}

White solid; $0.18 \mathrm{~g}$ (85\% yield), $R_{\mathrm{f}} 0.76\left(\mathrm{PE} / \mathrm{Et}_{2} \mathrm{O}=10 / 1\right), \mathrm{mp}=$ 68-70 ${ }^{\circ} \mathrm{C}$. ${ }^{1} \mathrm{H}$ NMR (500.17 MHz, $\left.\mathrm{CDCl}_{3}, 25{ }^{\circ} \mathrm{C}\right): \delta=0.91-0.93$ $\left(\mathrm{m}, 3 \mathrm{H}, \mathrm{CH}_{3}\right), 1.30-1.46\left(\mathrm{~m}, 4 \mathrm{H}, \mathrm{CH}_{2}\right), 1.61-1.62\left(\mathrm{~m}, 4 \mathrm{H}, \mathrm{CH}_{2}\right)$, 1.98-2.03 (m, 1H, CH) 5.20-5.35 (m, 2H, 2CH). ${ }^{13} \mathrm{C}$ NMR (125.78 $\left.\mathrm{MHz}, \mathrm{CDCl}_{3}, 25{ }^{\circ} \mathrm{C}\right): \delta=20.5,22.6,22.7,25.0,25.2,31.2,31.6$, 32.0, 32.7, 90.3, 91.2, 113.5. MALDI TOF/TOF, $m / z: 219[\mathrm{M}-\mathrm{H}]^{+}$. Anal. calcd for $\mathrm{C}_{9} \mathrm{H}_{16} \mathrm{O}_{6}$ : C, 49.09; H, 7.32\%. Found: C, 49.07; H, $7.30 \%$.

\section{Crystal structure determination and refinement}

The crystallographic data, coordinates of atoms, and geometric parameters for compounds $\mathbf{4 a}, \mathbf{4 b}, \mathbf{4 d}, \mathbf{4 e}, \mathbf{1 2}$ bere deposited at the Cambridge Crystallographic Data Centre as a CIF deposition with file number CCDC 1905323, 1905327, 1905330, 1905341, 1905334, 1905337, respectively.

Crystal data for 4 b. Crystals of $\mathrm{C}_{20} \mathrm{H}_{22} \mathrm{~F}_{2} \mathrm{~N}_{2} \mathrm{O}_{4}(M=392.40)$ are monoclinic, space group $P 2_{1} / c, a=18.9061(6), b=$ 11.4711(4) and $c=8.7831(3) \AA, \beta=99.134(3)^{\circ}, V=1880.66(11)$ $\AA^{3}, d_{\text {calc }}=1.386 \mathrm{~g} \mathrm{~cm}^{-3}, Z=4, \mu=0.110 \mathrm{~mm}^{-1}, 2 \theta_{\max }=$ $58.302^{\circ}, 9078$ reflections were measured, from which 4395 were independent. The refinement converged to $R_{1}=0.0544, \mathrm{w} R_{2}=$ 0.1617 , GOF $=1.030$.

Crystal data for 4a. Crystals of $\mathrm{C}_{20} \mathrm{H}_{22} \mathrm{Cl}_{2} \mathrm{~N}_{2} \mathrm{O}_{4}(M=425.30)$ are monoclinic, space group $\mathrm{P} 21 / n, a=10.5362(9), b=9.4705(6)$ and $c=20.3165(17) \AA, \beta=99.462(8)^{\circ}, V=1999.7(3) \AA^{3}, d_{\text {calc }}=$ $1.413 \mathrm{~g} \mathrm{~cm}^{-3}, Z=4, \mu=0.354 \mathrm{~mm}^{-1}, 2 \theta_{\max }=58.562^{\circ}, 13245$ reflections were measured, from which 4644 were independent. The refinement converged to $R_{1}=0.0608, \mathrm{w} R_{2}=0.1916, \mathrm{GOF}=$ 0.987 .

Crystal data for 4d. Crystals of $\mathrm{C}_{20} \mathrm{H}_{22} \mathrm{~F}_{2} \mathrm{~N}_{2} \mathrm{O}_{4}(M=392.40)$ are monoclinic, space group $\mathrm{P} 21 / n, a=12.9687(13), b=$ $10.0294(8)$ and $c=14.5182(15) \AA, \beta=100.068(10)^{\circ}, V=$ $1859.3(3) \AA^{3}, d_{\text {calc }}=1.402 \mathrm{~g} \mathrm{~cm}^{-3}, Z=4, \mu=0.111 \mathrm{~mm}^{-1}, 2 \theta_{\max }$ $=58.232^{\circ}, 9607$ reflections were measured, from which 4313 were independent. The refinement converged to $R_{1}=0.0825$, $\mathrm{w} R_{2}=0.2015, \mathrm{GOF}=1.026$.

Crystal data for 4e. Crystals of $\mathrm{C}_{20} \mathrm{H}_{22} \mathrm{Br}_{2} \mathrm{~N}_{2} \mathrm{O}_{4}(M=514.20)$ are monoclinic, space group $\mathrm{P} 2{ }_{1} / n, a=10.6640(6), b=9.4362(6)$ and $c=20.7558(11) \AA, \beta=97.997(5)^{\circ}, V=2068.3(2) \AA^{3}, d_{\text {calc }}=$ $1.651 \mathrm{~g} \mathrm{~cm}^{-3}, Z=4, \mu=3.948 \mathrm{~mm}^{-1}, 2 \theta_{\max }=58.354^{\circ}, 9852$ reflections were measured, from which 4798 were independent. The refinement converged to $R_{1}=0.0749, \mathrm{w} R_{2}=0.1777, \mathrm{GOF}=$ 0.986.

Crystal data for 12b. Crystals of $\mathrm{C}_{17} \mathrm{H}_{22} \mathrm{FNO}_{4}(M=323.36)$ are triclinic, space group $P \overline{1}, a=6.4738(3), b=10.2056(9)$ and $c=$ 12.4931(10) $\mathrm{A}, \alpha=75.029(7)^{\circ}, \beta=80.670(6)^{\circ}, \gamma=88.090(6)^{\circ}, V=$ 786.81(11) $\AA^{3}, d_{\text {calc }}=1.365 \mathrm{~g} \mathrm{~cm}^{-3}, Z=2, \mu=0.104 \mathrm{~mm}^{-1}$, $2 \theta_{\max }=58.558^{\circ}, 6406$ reflections were measured, from which 3602 were independent. The refinement converged to $R_{1}=$ $0.0472, \mathrm{w} R_{2}=0.1235, \mathrm{GOF}=1.022$.

Crystal data for 19. Crystals of $\mathrm{C}_{8} \mathrm{H}_{14} \mathrm{O}_{6}(M=206.19)$ are orthorhombic, space group Pbca, $a=6.5986(6), b=9.8591(8)$ 
and $c=29.604(2) \AA, \alpha=90^{\circ}, \beta=90^{\circ}, \gamma=90^{\circ}, \mathrm{V}=1925.9(3) \AA^{3}$, $d_{\text {calc }}=1.422 \mathrm{~g} \mathrm{~cm}^{-3}, Z=8, \mu=0.123 \mathrm{~mm}^{-1}, 2 \theta_{\max }=58.102^{\circ}$, 4693 reflections were measured, from which 1905 were independent. The refinement converged to $R_{1}=0.0953, \mathrm{w} R_{2}=$ $0.2238, \mathrm{GOF}=0.980$.

\section{Conflicts of interest}

There are no conflicts to declare.

\section{Acknowledgements}

This work was financially supported by the Russian Science Foundation (RSF projects 18-73-00014). The structural studies of the synthesized compounds were performed with the use of Collective Usage Centre "Agidel" at the Institute of Petrochemistry and Catalysis of RAS. The anticancer activity studies of the synthesized compounds were performed in laboratory of molecular design and biological screening of candidate substances for the pharmaceutical industry at the Institute of Petrochemistry and Catalysis of RAS.

\section{Notes and references}

1 (a) D. A. Casteel, Nat. Prod. Rep., 1992, 9, 289; (b) K. J. McCullough and M. Nojima, Curr. Org. Chem., 2001, 5, 601; (c) C. W. Jefford, in Comprehensive Heterocyclic Chemistry, ed. A. R. Katritzky, C. W. Rees and E. F. V. Scriven, Pergamon, Oxford, vol. 6, ch. 20, 1996; (d) R. K. Haynes and S. C. Vonwiller, Acc. Chem. Res., 1997, 30, 73; (e) A. K. Bhattacharya and R. P. Sharma, Heterocycles, 1999, 51, 1681; (f) Y. Dong, Mini-Rev. Med. Chem., 2002, 2, 113. For the synthesis of 1,2,4-trioxan-5-ones relevant to the present work, see; $(g)$ C. W. Jefford, J.-C. Rossier and G. D. Richardson, J. Chem. Soc., Chem. Commun., 1983, 1064; (h) C. W. Jefford, J. Currie, G. D. Richardson and J.-C. Rossier, Helv. Chim. Acta, 1991, 74, 1239.

2 K. J. McCullough, H. Tokuhara, A. Masuyama and M. Nojima, Org. Biomol. Chem., 2003, 1, 1522.

3 H.-S. Kim, Y. Nagai, K. Ono, K. Begum, Y. Wataya, Y. Hamada, K. Tsuchiya, A. Masuyama, M. Nojima and K. J. McCullough, J. Med. Chem., 2001, 44, 2357.

4 K. Tsuchiya, Y. Hamada, A. Masuyama, M. Nojima, K. J. McCullough, H.-S. Kim and Y. Wataya, Tetrahedron Lett., 1999, 40, 4077.

5 H.-S. Kim, K. Begum, N. Ogura, Y. Wataya, Y. Nonami, Y. Ito, A. Masuyama, M. Nojima and K. J. McCullough, J. Med. Chem., 2003, 46, 1957.

6 Y. Nonami, T. Tokuyasu, A. Masuyama, M. Nojima, K. J. McCullough, H.-S. Kim and Y. Wataya, Tetrahedron Lett., 2000, 41, 4681.

7 G.-H. Li, D.-Q. Dong, Q. Deng, S.-Q. Yan and Z.-L. Wang, Synthesis, 2019, 51, 3313.

8 F.-L. Zeng, X.-L. Chen, S.-Q. He, K. Sun, Y. Liu, R. Fu, L.-B. Qu, Y.-F. Zhao and B. Yu, Org. Chem. Front., 2019, 6, 1476.
9 K. Sun, Z. Liu, B. Luan, J. Zhu and Y. Xue, Org. Lett., 2018, 20, 6687.

10 X. Huang, N. Rong, P. Li, G. Shen, Q. Li, N. Xin, C. Cui, J. Cui, B. yang, D. Li, C. Zhao, J. Dou and B. Wang, Org. Lett., 2018, 20, 3332 .

11 C. Wu, X. Xin, Z.-M. Fu, L.-Y. Xie, K.-J. Liu, Z. Wang, W. Li, Z.-H. Yuan and W.-M. He, Green Chem., 2017, 19, 1983.

12 L.-H. Lu, Z. Wang, P. Cheng, B. Zhang, Z. Cao and W.-M. He, Chin. Chem. Lett., 2019, 20, 1237.

13 J. Fayos, D. Lokensgard, J. Clardy, R. J. Cole and J. W. Kirksey, J. Am. Chem. Soc., 1974, 96, 6785.

14 R. J. Cole, J. W. Kirsey, J. W. Dorner, D. M. Wilson, J. Johnson Jr, N. Johnson, D. M. Dedell, J. P. Springer, K. K. Chexel, J. Clardy and R. H. Cox, J. Agric. Food Chem., 1977, 25, 826.

15 C. Madelaine, O. Buriez, B. Crousse, I. Florent, Ph. Grellier, P. Retailleau and Y. Six, Org. Biomol. Chem., 2010, 8, 5591.

16 D. A. Casteel, Nat. Prod. Rep., 1999, 16, 55.

17 N. N. Makhmudiyarova, G. M. Khatmullina, R. Sh. Rakhimov, A. G. Ibragimov and U. M. Dzhemilev, ARKIVOC, 2016, 427.

18 N. N. Makhmudiyarova, G. M. Khatmullina, R. Sh. Rakhimov, E. S. Meshcheryakova, A. G. Ibragimov and U. M. Dzhemilev, Tetrahedron, 2016, 72, 3277.

19 T. V. Tyumkina, N. N. Makhmudiyarova, G. M. Kiyamutdinova, E. S. Meshcheryakova, K. Sh. Bikmukhametov, M. F. Abdullin, L. M. Khalilov, A. G. Ibragimov and U. M. Dzhemilev, Tetrahedron, 2018, 74, 1749.

20 (a) N. N. Makhmudiyarova, I. R. Ishmukhametova, T. V. Tyumkina, A. G. Ibragimov and U. M. Dzhemilev, Tetrahedron Lett., 2018, 59, 3161; $\quad$ (b) N. N. Makhmudiyarova, I. R. Ishmukhametova, L. U. Dzhemileva, T. V. Tyumkina, V. A. D'yakonov, A. G. Ibragimov and U. M. Dzhemilev, RSC Adv., 2019, 9, 18923.

21 (a) G. Verardo, A. G. Giumanini, G. Favret and P. Strazzolini, Synthesis, 1991, 447; (b) B. Li, S. Liu, M. Wu, Q. Lin, W. Deng, Sh. Jiang and L. Chen, Tetrahedron Lett., 2018, 59, 3467.

22 (a) C. Denekamp, L. Gottlieb, T. Tamiri, A. Tsoglin, R. Shilav and M. Karon, Org. Lett., 2005, 7, 2461; (b) N. Haroune, A. Crowson and B. Campbell, Sci. Justice, 2011, 51, 50.

23 N. N. Makhmudiyarova, R. Sh. Rakhimov, T. V. Tyumkina, E. S. Meshcheryakova, A. G. Ibragimov and U. M. Dzhemilev, Russ. J. Org. Chem., 2019, 5, 620.

24 (a) M. J. Frisch, G. W. Trucks, H. B. Schlegel, G. E. Scuseria, M. A. Robb, J. R. Cheeseman, G. Scalmani, V. Barone, B. Mennucci, G. A. Petersson, H. Nakatsuji, M. Caricato, X. Li, H. P. Hratchian, A. F. Izmaylov, J. Bloino, G. Zheng, J. L. Sonnenberg, M. Hada, M. Ehara, K. Toyota, R. Fukuda, J. Hasegawa, M. Ishida, T. Nakajima, Y. Honda, O. Kitao, H. Nakai, T. Vreven, J. A. Montgomery, J. E. Peralta Jr, F. Ogliaro, M. Bearpark, J. J. Heyd, E. Brothers, K. N. Kudin, V. N. Staroverov, T. Keith, R. Kobayashi, J. Normand, K. Raghavachari, A. Rendell, J. C. Burant, S. S. Iyengar, J. Tomasi, M. Cossi, N. Rega, J. M. Millam, M. Klene, J. E. Knox, J. B. Cross, V. Bakken, C. Adamo, J. Jaramillo, R. Gomperts, R. E. Stratmann, 
O. Yazyev, A. J. Austin, R. Cammi, C. Pomelli, J. W. Ochterski, R. L. Martin, K. Morokuma, V. G. Zakrzewski, G. A. Voth, P. Salvador, J. J. Dannenberg, S. Dapprich, A. D. Daniels, O. Farkas, J. B. Foresman, J. V. Ortiz, J. Cioslowski and D. J. Fox, GAUSSIAN 09 (Revision D.01), Gaussian, Inc., Wallingford, CT, 2013; (b) A. D. Becke, J. Chem. Phys., 1993, 98, 5648; (c) C. Lee, W. Yang and R. G. Parr, Phys. Rev. B, 1988, 37, 785; (d) P. J. Stephens, F. J. Devlin, C. F. Chabalowski and M. J. Frisch, J. Phys. Chem., 1994, 98, 11623.

25 Agilent Technologies Ltd, CrysAlis PRO, Yarnton, Oxfordshire, England, 2012.
26 O. V. Dolomanov, L. J. Bourhis, R. J. Gildea, J. A. K. Howard and H. Puschmann, J. Appl. Crystallogr., 2009, 42, 339.

27 G. M. Sheldrick, Acta Crystallogr., Sect. A: Found. Crystallogr., 2008, 64, 112.

28 C. F. Macrae, P. R. Edgington, P. McCabe, E. Pidcock, G. P. Shields, R. Taylor, M. Towler and J. Van De Streek, J. Appl. Crystallogr., 2006, 39, 453.

29 A. O. Terent'ev, M. M. Platonov, E. J. Sonneveld, R. Peschar, V. V. Chernyshev, Z. A. Starikova and G. I. Nikishin, J. Org. Chem., 2007, 72, 7237c. 